\title{
Colonial Encounters in Lucayan Contexts
}

\author{
Mary Jane Berman and Perry L. Gnivecki
}

\section{1 \\ Introduction}

Consumption patterns are informed by context, so, when studying indigenous consumption of European items, it is necessary to consider how colonial contexts varied (Dietler 1998; Lightfoot and Simmons 1998; Oland 2014, 646). Much of what has been written about the indigenous consumption of European artifacts during the early period of Spanish colonialism of the Caribbean has focused on the patterns observed at colonial settler sites such as La Isabela (Deagan 1988; Deagan and Cruxent 2000a,b), Puerto Real (Deagan 1995), and Concepción de la Vega (Ortega and Fondeur 1978) on Hispaniola or encomienda sites such as El Chorro de Maíta on Cuba (Valcárcel Rojas 2016). At these sites, the indigenous occupants and the Spanish lived and worked in close proximity under colonial scrutiny in mines, workshops, fields, and households (Kulstad-González 2015; Valcárcel Rojas et al. 2013).

Indigenous sites located on the geographic and political frontiers of colonial settlements also offer insights about local consumption of European goods during the early period of Spanish colonization. These communities were not subject to the same level of regulation as those in the colonial centers and their autonomy offered different opportunities for indigenous agency (Lightfoot and Martinez 1995; Oland 2014). In some cases, local peoples did not have direct contact with the Spanish, but acquired European objects by way of down-theline trade. Such was the case of El Cabo, an indigenous site in southeastern Dominican Republic, which did not experience direct colonial control during the early years of colonization of Hispaniola (Hofman et al. 2014; Samson 2010; Valcárcel Rojas et al. 2013).

The Bahama archipelago, home to the Lucayans, the indigenous occupants of these islands, offers another opportunity to view native consumption of European goods during the early period of Spanish colonization. The Spanish regarded the Bahama Islands as useless, referring to them as islas inútiles (Anderson-Córdova 2017, 131) and did not establish settler communities or institute the encomienda system here as they did elsewhere in the Antilles. With the decimation of many of its indigenous inhabitants and the formal establishment of the encomienda system on Hispaniola in 1503, the Spanish 
turned to the Bahamas to secure labor, and the Lucayans were brought to the Antilles as slaves and naborías (Anderson-Córdova 2017; Sauer 1966). Since we view colonialism as the "process by which a city or nation-state exerts control over people - termed indigenous - and territories outside of its geographical boundaries" (Silliman 2005, 58), it can be said that the Bahamas functioned as a colonial "space," or frontier impacted by Spanish policies and practices. In this chapter, we examine the historical and cultural contexts in which Lucayan consumption of European objects occurred and the processes by which they were transformed into indigenous objects.

Studies have shown that European objects were integrated differently and for a variety of different reasons into indigenous systems of use. In areas falling under Spanish colonial rule, indigenous people were selective in what European objects they incorporated, accepting them at varying rates or not at all (Charlton 1968; Cobb 2003; Rodríguez-Alegría 2008; Rodríguez-Alegría et al. 2015). The scarcity of Spanish objects at En Bas Saline, a Taíno site located adjacent to the early colonial site of Puerto Real, for example, has been attributed to native "indifference to and rejection" of Spanish culture (Deagan 2004).

In colonial contexts, indigenous and European items were often transformed physically and given new meanings and uses as they crossed cultural borders (sensu Kopytoff 1986; Thomas 1991). Thomas (1991) and Cipolla (2017, 18) note, however, that such physical modification of European objects in indigenous contexts occurred infrequently. In his study of the Brothertown Indians of New England, Cipolla (2013, 2017, 18) observed no physical alterations of European-made artifacts. In the Caribbean, indigenous objects were changed occasionally to resemble European items, while some European objects were modified to look like native objects (Deagan 1988; Hofman et al. 2014; Rouse 1942). In short, there is limited evidence for such modifications. Cusick (1991, $45^{2}$ ) has suggested that we begin to see significant "Europeanization" of or other changes in indigenous material culture only with the relocation of the Taíno (indigenous populations) to towns or encomiendas, contexts where cultures experienced major changes in social structure and cultural coherence. For example, native pottery did not show any evidence for the incorporation of Spanish elements at En Bas Saline (Cusick 1991). In contrast, the indigenous pottery at Puerto Real exhibited European attributes with the creation of the Spanish settlement (Deagan 1988, 214). Such hybrid forms retained traditional uses or were given new meanings or new uses. Keehnen's chapter (this volume) adds to the database of these kinds of objects in Hispaniola. Other items remained unchanged physically, but given new purposes, and assigned new meanings, as Valcárcel Rojas (2016) observed at a number of sites in Cuba, such as El Chorro de Maíta. Finally, European items, such as glass beads, mirrors, 
and brass ornaments were occasionally incorporated into Taíno material culture, such as belts and sculptures (Ostapkowicz 2018).

In addition to studying context, we are also interested in the length of time it took for European objects to be modified or assimilated into indigenous contexts in early colonial situations. In our study, we examine a time frame of less than 40 years (1492-1530). In this example, contact and interaction were brief and sporadic and did not result in the establishment of settlements where interaction was prolonged or continuous. By reframing our questions, reconsidering our assumptions, and reexamining the evidence, we present a new narrative of Lucayan acquisition and consumption of European items.

\section{$2 \quad$ Setting the Stage for Consumption}

There were numerous documented ways that the Lucayans interacted with the Spanish and acquired and consumed European objects (Dunn and Kelley 1989). These included direct trade, exchange, and theft. Other possible means include securing items from shipwrecks or vessels that stopped on the islands for repair or careening. Intra- and inter-island distribution of European objects was likely to have occurred through indirect means such as down-the-line exchange (Gnivecki 1995, 2011; Keegan 1992).

The first known direct engagement between the Spanish and the Lucayans occurred in 1492 when Columbus and his men made landfall on the island of Guanahaní, known today as San Salvador (Dunn and Kelley 1989; Morison 1942). Here they participated in trade and exchange and the Spanish took six men captive. This was followed by visits to several other Lucayan islands where the Spanish traded and exchanged objects with the local peoples. Soon after, explorers, traders, and enslavers passed through the archipelago (Table 2.1).

TABLE 2.1 Spanish activity in the Bahama archipelago (1492-1530)

Date Individual(s) Involved References

\begin{tabular}{lll}
\hline 1492 & Cristoforo Colón & Dunn and Kelley $(1989,57-117)$ \\
$1499-1500$ & Juan de la Cosa & Parry and Keith $(1984:$ II, 147) \\
$1499-1500$ & Alonso de Hojeda & Sauer $(1966,112,159)$ \\
$1499-1500$ & Vincente Yáñez Pinzón & $\begin{array}{l}\text { Burns }(1965,90-91) ; \text { Quinn } \\
(1979: I, 234-235,237-238)\end{array}$ \\
& & Parry and Keith $(1984:$ II, 163-164)
\end{tabular}




\begin{tabular}{|c|c|c|}
\hline Date & Individual(s) Involved & References \\
\hline 1508 & Lucas Vásquez de Allyón & Anderson-Córdova $(2017,134)$ \\
\hline $1508-1509$ & Nicolás de Ovando & Sauer $\left(1966,15^{8-159)}\right.$ \\
\hline $1508-1509$ & Alonso de Hojeda & Anderson-Córdova $(2017,131)$ \\
\hline $1508-1509$ & Diego de Nicuesa & Anderson-Córdova $(2017,131)$ \\
\hline $15^{13}$ & Juan Ponce de León & $\begin{array}{l}\text { Kelley }(1991,41-42 \text {, Footnote } 22 \text {, } \\
52) \text {; Weddle }(1985,40)\end{array}$ \\
\hline 1513 & Diego Miruelo & Weddle $(1985,46)$ \\
\hline $15^{13}$ & Juan Bono de Quejo & Weddle $(1985,40)$ \\
\hline $15^{13^{-1}} 5^{14}$ & Antón de Alaminos & $\begin{array}{l}\text { Quinn (1979:I, 237-238); Weddle } \\
(1985,40)\end{array}$ \\
\hline $15^{13^{-1}} 5^{14}$ & Diego Bermúdez & $\begin{array}{l}\text { Quinn (1979 I, 237-238); Weddle } \\
(1985,40)\end{array}$ \\
\hline $15^{1} 3^{-1} 5^{14}$ & Juan Pérez de Ortubia & Weddle $(1985,40)$ \\
\hline 1514 & Diego Velázquez & Anderson-Córdova $(2017,141)$ \\
\hline $15^{14-1516}$ & Pedro de Salazar & Hoffman $(1990,6)$ \\
\hline $15^{14-1517}$ & Francisco Gordillo & Hoffman $(1990,5)$ \\
\hline $15^{14-1517}$ & Toribio de Villafranca & Hoffman $(1990,5)$ \\
\hline $15^{15^{-1}} 5^{16}$ & Diego Velázquez & Weddle $(1985,55)$ \\
\hline 1517 & Diego Velázquez & Anderson-Córdova $(2017,141)$ \\
\hline 1519 & Francisco de Barrionuevo & Parry and Keith (1984:II, 390) \\
\hline 1521 & Lucas Vásquez de Allyón & $\begin{array}{l}\text { Hoffman (1990); Quinn (1979:I, } \\
248,255,257)\end{array}$ \\
\hline $15^{21}$ & Francisco Gordillo & Hoffman (1990, 6-7) \\
\hline $15^{21}$ & Pedro de Quijos & $\begin{array}{l}\text { Hoffman (1990, 6-7); Quinn } \\
(1979: \text { I, 257-258) }\end{array}$ \\
\hline 1521 & Alonso Fernández Sotil & Hoffman $(1990,7)$ \\
\hline 1521 & Juan Ponce de León & Ober $(1908,197)$ \\
\hline 1525 & Pedro de Quijos & Hoffman (1990, 36-37) \\
\hline $15^{26}$ & Lucas Vásquez de Allyón & Hoffman $(1990,44,55)$ \\
\hline $15^{21-1526}$ & Bahamas depopulated & Quinn (1979:I, 258, 265) \\
\hline
\end{tabular}

Note: It is believed that the Highborne Key and Molasses Reef wrecks in Bahamian waters date to this period, but they have not been securely dated (Keith et al. 1984; Smith et al. 1985). Thus, they are excluded from this table. For the sake of brevity, we have mentioned only royal decrees of enslavement authorization. See Anderson-Córdova (2017) for the details of royal and local authorization of enslavement beyond Hispaniola and Puerto Rico. 
Subsequent visits brought the Lucayans and Spanish into direct contact. In spite of the number of visits, however, such interactions were limited to short, irregular encounters.

Shipwrecks may have been significant sources of European goods (Turnbaugh 1993, 136) and in the Bahamas, as well as other coastal contexts, shipwrecked sailors offered opportunities for Spanish items to be traded, exchanged, or given as gifts, and grounded ships presented chances for items to be pilfered and scavenged (Gnivecki 1995, 2011). The numerous reefs and shoals of the archipelago and the destructive forces of hurricanes posed great challenges for fifteenth- and sixteenth-century seafaring, resulting in numerous shipwrecks (Sauer 1966). Although only two ships from that period, the Molasses Reef wreck (Keith et al. 1984) in 1499 and the Highbourn Cay wreck, one of the ships lost by Pinzón in 1500 (Smith et al. 1985) have been found, it is probable that many more went aground.

The acquisition of wood and water from the islands to provision ships offered occasions for Lucayan-Spanish exchanges. Stopping at islands for ship maintenance and repairs must have also brought Lucayans and Spanish in direct contact. Keegan $(1992,213)$ suggests that during late 1499 and early 1500 Vespucci may have established short-term encampments on several islands, in order to careen his vessel during his journey through the islands. (The trip included taking of Lucayan slaves, see below). These would have provided occasions for the introduction of European items. Spanish ships from this and other expeditions may also have moored close to shore as they passed through the islands and the Lucayans may have swum out to the boats to procure goods, as they did during Columbus' voyage (Dunn and Kelley 1989). The ship captains may have sent their crew in small boats to shore, as well, to engage in trade and exchange.

Spanish maps from the early and middle 1500 suggest that considerable shipping traffic took place through the archipelago during this period (Granberry 1979, 1980, 1981). Numerous secret missions by unnamed European powers also likely occurred (Harisse 1961; Keegan 1992, 207). Items may have been lost, discarded, or traded during passage through the islands, as the sailors associated with these activities stopped to secure fresh water, make repairs, investigate the landscape, or take captives (Keegan 1992, 203). The appropriation of items from shipwrecks and/or shipwrecked sailors, the procurement of items that washed up on shore from shipwrecks, the seizure of items from careened ships, and trade and exchange with sailors on the many expeditions that passed through the Bahamas during this period are all means by which European items found their way into Lucayan hands.

Spanish removal of the Lucayans began in the early days of colonization, although we have no written records to that effect until 1499. There is 
documentary evidence of at least 232 Lucayans having being taken by force to Spain by Amerigo Vespucci during his four month passage through the Bahamas (Keegan 1992, 212; Sauer 1966, 112, 159). During the early 1500s, Lucayans were brought to Hispaniola as naborías, but functioned as slaves and were sold illegally (Anderson-Córdova, 2017, 145). In 1508, raiding in the Bahamas was recognized legally and the following year the Crown decreed that those who resisted capture were to be designated as slaves (Anderson-Córdova 2017, 131). Even though the greatest period of enslavement occurred during 1509-1515 (Sauer 1966), such activity continued for at least another decade. In 1517, privately financed slave ships, commissioned by Governor Diego Velazquez of Cuba, set out from Santiago de Cuba, to secure Lucayan slaves to work on Cuba (Sauer 1966); that year 300 Indians from Bimini and Florida were taken to Puerto Rico (Anderson-Córdova 2017, 141). In 1518, privately financed slave ships originating from Puerto Plata and Santiago brought shiploads of Lucayans, as well as individuals from other islands, to Hispaniola (Anderson-Córdova 2017, 137; Sauer 1966). In 1520 Lucayans who had been taken to Hispaniola were sent to Nueva Cádiz to work in the pearl beds (Granberry 1979). The exact number of Lucayans brought to the Antilles varies between 20,000-40,000 people; of those captured, anywhere from 800 to 5000 people survived transport (Anderson Córdova 2017, 136-137). Lucayans may have been lured to ships through the enticement of European goods, although, according to Las Casas [in Granberry $(1979,15)]$, actual enslavement was achieved with "sword and lance." As an example, Pohl $(1966,87)$ in Keegan $(1992,212)$ notes that Vespucci took captives "by force." While no record exists as to how many such expeditions took place, Keegan $(1992,221)$ has projected that at least for the purposes of enslavement, 320 vessels may have traveled through the islands. The archipelago was ultimately depopulated by $\mathbf{1 5 2 0}^{20} \mathbf{1 5 3 0}$, primarily through these actions (Gnivecki 1995; Granberry 1981, 18).

The Long Bay site, located on the western side of San Salvador (Figure 2.1), has yielded the greatest number of Spanish artifacts of any site in the archipelago. Three other excavated sites, the Three Dog site on San Salvador (Berman and Gnivecki 1995), MC-6 on Middle Caicos (Sullivan 1981), and CC-6 on Cotton Cay (Sinelli 2010), have each produced one or two Spanish objects. Surface finds of earthenware sherds have been found on Long Island, Little Exuma, Acklins Island, Conception Island, and Samana Cay (Keegan 1992), and Middle Caicos (Sinelli 2010). Some of these finds are associated with archaeological sites; others are isolated finds (Keegan 1992). Two shipwreck sites (Keith et al. 


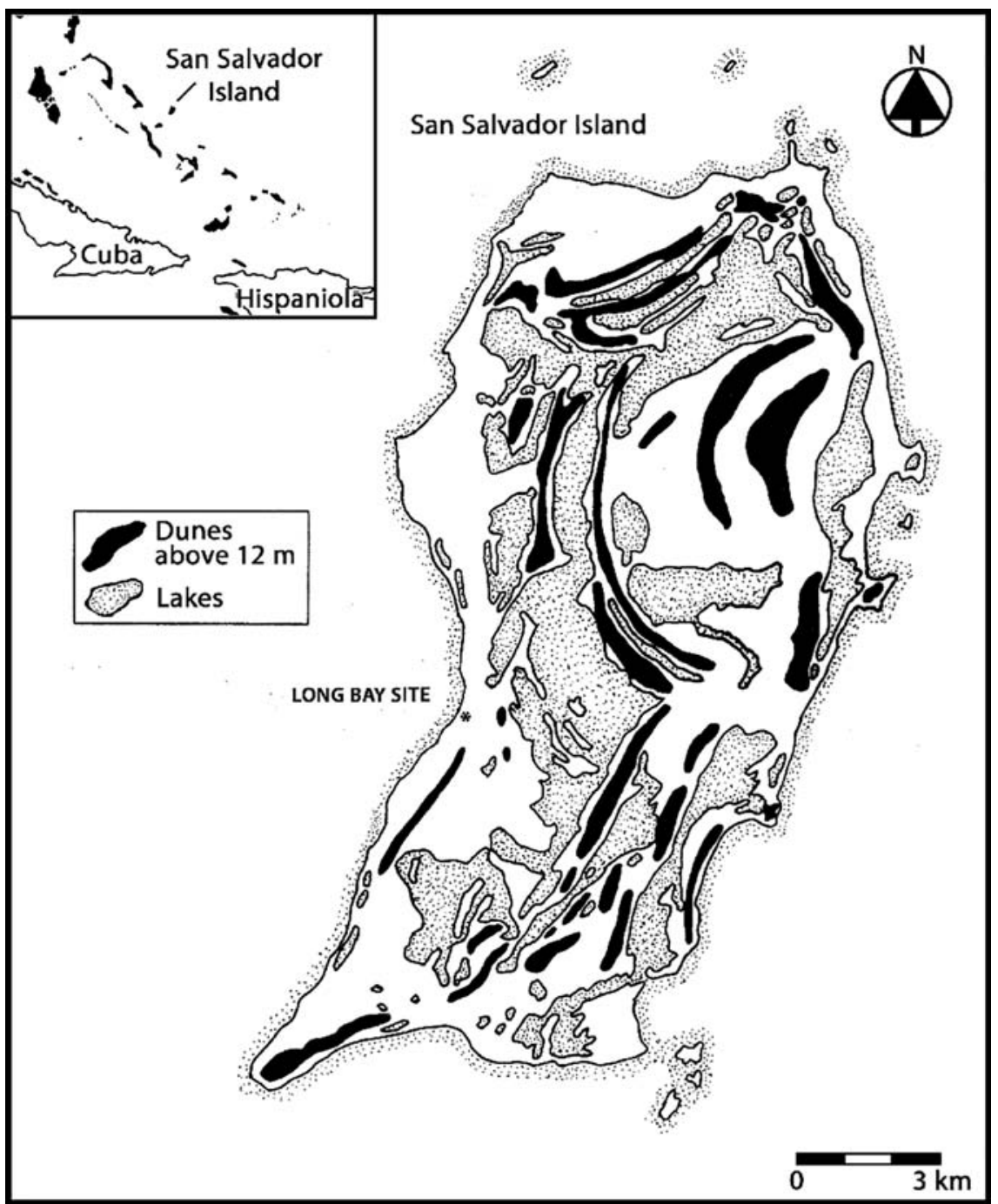

FIGURE 2.1 Map of the Bahamas and San Salvador Island MAP DRAWN BY PERRY L. GNIVECKI

1984; Peterson 1974; Smith et al. 1985) have also produced ordnance and other artifacts of European origin.

The Long Bay Site is considered one of the earliest sites of contact between the Lucayans and the Spanish in the Bahama archipelago, although it is not known whether the European items made their way to the site through direct intercultural encounter or indirect means. The archaeologist Charles Hoffman, who excavated a portion of it between 1983-1992, sought to demonstrate that it was the Columbus landing site and theatre for direct contact between the 
indigenous peoples and the Spanish (Hoffman 1987a, 1987b). In the late 199os, the construction of a house threatened to destroy the northern part of the site, so efforts to recover what the builders had not yet disturbed or removed from that area were instituted by John Winter, in 1999, and Berman and Gnivecki, in 2000. In 2008, Gnivecki mapped the whole site, and, in 2012, he and his students dug several units to the west of where Hoffman had worked. All the researchers conducted their excavations in $10 \mathrm{~cm}$ levels in $1 \times 1$ and $2 \times 1$ meter square units and shovel test pits. A total of 191.5 square meters has been excavated. The use of $1 / 16$-inch mesh screen, allowed for the capture of tiny objects, such as European glass beads $\left(2.5^{-} 3.5 \mathrm{~mm}\right.$ in diameter), which otherwise may have not been recovered.

The Long Bay site inhabitants' lifeways resembled those described for other Lucayan settlements from this time period (Berman et al. 2013). They were fisher-horticulturalist-shellfish collectors who fished and collected from nearby reefs and intertidal habitats (Newsom and Wing 2004), grew root and seed crops (Berman and Pearsall 2008, 2018), and gathered and possibly managed some wild plants, including palms and fruit trees (Berman and Pearsall 2018). Food procurement, processing, and preparation implements, ceramics, woodworking tools, body adornments, and ceremonial items were manufactured from local and non-local materials. The residents engaged in down-the-line or direct trade and exchange with other Lucayans and people from islands outside the Bahama archipelago, as the site yielded a number of imported items including ceramics and stone tools. One sherd has been sourced to northern Cuba (Winter and Gilstrap 1991). Non-local indigenous (i.e., Antillean) ceramics made up 3.2 per cent and Spanish ceramics constituted 3.1 per cent of the ceramic assemblage (Bate 2011, 216).

Only a portion of the site was excavated. No discrete house structure(s) could be inferred from the postholes, which were located to the northeast and southwest of where the excavations were concentrated. Similarly, neither middens nor distinct activity areas have yet to be discerned from the artifact patterning. The Spanish objects, which cluster in the northeastern part of the site, were found at a depth of 10-40 $\mathrm{cm}$ below the surface intermixed with a typical Late Lucayan domestic assemblage. The assemblage included Lucayan ceramics (plain ware and red-slipped Palmetto ware sherds, Palmetto ware basketryimpressed sherds, and a handful of Palmetto ware incised or appliqué sherds) (Bate 2011), shell beads, and shell bead débitage; food debris from local sources, such as fish (e.g., parrotfish and other reef fish) (Newsom and Wing 2004) and whole shells and shellfish fragments (e.g., Lobatus gigas, Codakia orbicularis, Nerita sp., Cittarium pica), procured from in-shore and rocky intertidal areas. Non-local ceramic sherds and stone objects (e.g., greenstone fragments, including jadeite, quartz microliths and cores) were also recovered. We interpret the 
area where the European goods were found as generalized floor debris, the consequence of repeated discard, loss, and sweeping episodes in one or more small household areas. It would be premature to say how many households were present or if they were associated with one or more elite households, however.

The excavated European objects include six or more green glass beads and three glass bead fragments, one amber glass bead, 38 melado sherds, two majolica (Columbia Plain) sherds, unglazed earthenware sherds, one reconstructed half of an early-style olive jar, 10 planking nails (ship spikes), two metal hooks, four metal knife blade fragments, a bronze " $\mathrm{D}$ "-ring, a bronze belt buckle, a copper grommet, a blanca (coin), a metal button, metal fragments, and fragments of green glass (Bate 2011; Hoffman 1987a, 1987b, 241-242). The translucent green glass beads are known as abalorios, wire-wound beads that held little value to the Spanish (Deagan 1987, 157). Glazed and unglazed sherds of Spanish origin including melado and majolica wares are scattered on the surface, particularly in the southern sector of the site (Berman and Gnivecki 2000). Hoffman reconstructed part of an early-style Spanish olive jar from sherds recovered from the southeastern part of the site, adjacent to a low-lying depression that fills up with water during the rainy season (Bate 2011). During the summer of 2017, we determined that the button and green glass shards were of later origin and that Hoffman recovered more Spanish objects during the later years of his excavations (post 1987).

Chemical analyses of some of the European artifacts, conducted by the Corning Museum of Glass (Brill et al. 1987), point to their origins in the Iberian Peninsula, matching particular source areas in Portugal and Spain. Several have been keyed to specific workshops in Spain. Descriptions and the chemical analyses of the beads, " $\mathrm{D}$ "-ring, belt buckle, and sherds are summarized in Table 2.2.
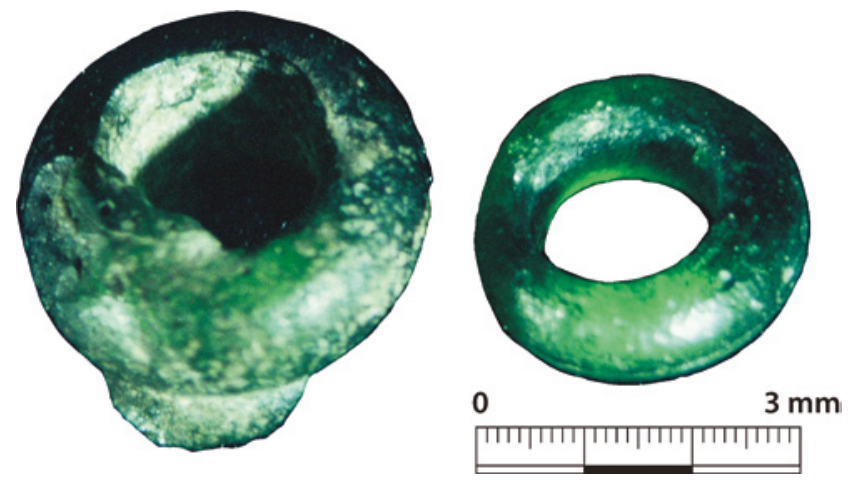

FIGURE 2.2 Green glass beads from the Long Bay Site, San Salvador Island PHOTO COURTESY OF KATHY DOAN GERACE 


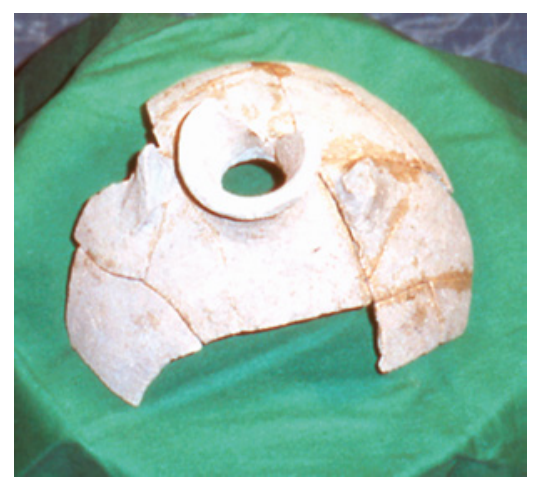

FIGURE 2.3

Reconstructed Spanish olive jar from the Long Bay Site, San Salvador Island

TABLE 2.2 European artifact descriptions

Coin (Brill 1987 et al., 255-257, 259, 280-281)

This blanca is a small-denomination billion coin issued between 1471-1474 during the reign of King Henry IV. It is a small denomination billion (copper alloy) coin of low value. The diagnostic images of a castle and a floret on one side and a lion on the other can be made out, although the coin is corroded. There is some evidence of lettering, as well. According to Stahl (1992, 4-5), a blanca such as this would have been the only small-denomination coin circulating in Spain in 1492 and 1493. Through electron microprobe analysis, the investigators determined that the coin was made of billion and contains 3.97 per cent silver. It was most likely minted in Segovia and Burgos, Spain, but the lead resembles that from the Albergaria-a-Velha galena source located near Aveiro, Portugal.

Glass Beads (Brill et al. 1987, 250-253, 259, 278)

Seven glass beads and three bead fragments were analyzed. The beads are doughnut-shaped, $2.5^{-3.5} \mathrm{~mm}$ in diameter, with circular holes for suspension measuring $1.5^{-2.3} \mathrm{~mm}$ in diameter. They were manufactured using the wire-wound technique. Hoffman $(1987 \mathrm{~b}, 242)$ states that this bead type was manufactured until 1516. The analysts described the green beads as possessing a "sparkling" color. The green color is due to the addition of a copper-containing colorant, such as scrap brass. The beads share physical and manufacturing similarities with early colonial Spanish bead types VIDle and VIDlf featured in Smith and Good (1982). Electron microprobe analysis indicates that the beads possess unusually elevated levels of lead oxide, much higher than those found in other early lead glasses. Their chemical composition is very similar to one another leading the analysts to suggest 
that they were manufactured in the same factory or workshop. The location of the manufacturing site or the source of the materials used in the bead manufacture is on the Iberian peninsula. Two of the green glass beads possess lead that is a "close match" to the galena mined at Albergaria-a-Velha, near Aveiro, Portugal.

D-ring (Brill 1987 et al. 254, 259, 280)

The bronze D-ring bears a close resemblance to fifteenth-century clothing and armor buckles pictured in Deagan (2002, 180-188), but, it is not a direct match, and Brill et al. (1987) suggest it had a decorative or maritime function. Its chemical composition was analyzed using atomic absorption and emission spectrography. The ore matches a galena ore source from Albergaria-a-Velha in Portugal. The shank is $2.7 \mathrm{~cm}$ in length.

Belt Buckle (Brill et al. 1987, 253, 259-26o, 279)

The belt buckle is small and lacks a tongue suggesting that it might have been a mock buckle made to function as a trade gewgaw, not unlike, in concept, to other trade trinkets brought by explorers and slavers to the Americas and Africa. The buckle bears some resemblances in form and size, though, to a Spanish shoe buckle that was common in the fifteenth century and manufactured up to 1485 . X-ray fluorescence determined that it was made of a lightly leaded bronze. The lead is similar to that from the Los Belgas mine in the Sierra de Gador, near Almeria, a city located in Andalusia, Spain. The length of the shank is $2.0 \mathrm{~cm}$.

Melado and Majolica Wares (Brill et al. 1987, 254-255, 260, 282)

The majolica was identified as Columbia Plain. Using a variety of sourcing techniques, such as x-ray diffraction and thin-section analysis, it was determined that the clay from the two sherds submitted for analysis originated from clay sources located in southern Spain. Both sherds possess a lead glaze that is indistinguishable from one another, suggesting they were manufactured from closely located workshops. The lead in the glaze is sourced to Rio Tinto, an area in southwestern Spain rich in minerals. The Colombia Plain glaze also contains tin.

Columbus' diary and other historic accounts of his first voyage serve as useful sources of information about how exchange was negotiated with indigenous peoples at this time. From them - particularly the diary - we learn what items Columbus and his men gave the Lucayans. Many of these items have also been 
found at sixteenth-century Spanish settlement sites elsewhere in the Caribbean suggesting that these goods were components of "gift kits" (sensu Brain 1975), which functioned to establish relations with indigenous peoples. The choice of the contents was influenced likely by the kinds of items that the Portuguese brought to Africa during their fifteenth-century exploratory ventures and slaving expeditions. Morison $(1942,305)$ notes that Columbus brought things that the Portuguese "had found to be most in demand" among the West Africans. Benjamin $(2009,83)$ reports that in 1479, Portuguese expeditions secured West African slaves through the exchange of cloth, brass, shells, wine, and beads. Items mentioned in the Columbus diary include strings of green and yellow glass beads, coins, broken pieces of pottery and glass cups, lace ends, red caps (bonnets), brass bells, brass jingles, and miscellaneous items, many of trifling value to the Europeans (Dunn and Kelley 1989, 65, 71, 107, 81, 85, 87, 93). Materials such as the textiles did not survive the archaeological record. In spite of numerous references to hawk bells (cascabeles), none has been discovered at Lucayan sites. Items that were no longer minted such as the blanca or manufactured, like the belt buckle, found at the Long Bay site, were also gifted or exchanged.

While it is tempting to believe that the Long Bay site was the first example of Spanish-Lucayan contact due to the congruence of the European artifacts with those mentioned in the Columbus diary, it would be foolhardy to jump at such a conclusion. The Lucayans may have gained possession of such items in other ways and the historic record presents many situations where Spanish-Lucayan interactions in the Bahama archipelago might have occurred.

Establishing when the Long Bay site was established and abandoned and pinpointing the year or years of Spanish contact, either direct or indirect, proves to be challenging, due to the wide berth of time that both the Lucayan and Spanish artifacts found at the site were manufactured and consumed. Radiocarbon assays yielded contemporary dates, giving us no radiochronometic clues. The indigenous assemblage of artifacts (ceramics, shell beads, coral artifacts, stone tools) is typical for the latter part of the Late Lucayan period, which lasted from AD 1100 into the early to mid-sixteenth century (Berman et al. 2013). A few pieces of Lucayan pottery show design affinities with late Chicoid pottery, similar to that manufactured in Hispaniola during the Late Ceramic Age and early colonial period. The Spanish objects were manufactured and circulated over several decades during the late fifteenth and early to mid-sixteenth centuries.

The use of the early-style Spanish olive jar to date the period of Spanish contact at the Long Bay site fails to provide the tight chronological definition we are seeking, but its presence at other sites in the insular Caribbean is instructive. The initial manufacture of Spanish olive jars in Spain occurred as early as 1490; 
the style lasted to around 1570 when it was replaced by another form (Deagan $1987,31)$. Spanish olive jars or fragments were not found in the Spanish occupation of En Bas Saline, which consisted of a small contingent of 39 men whose ship, the Santa Maria, had run aground (Deagan 2004). Columbus and his men had salvaged the ship's cargo to provision themselves during Columbus' return to Spain. Neither Goggin $(1960,11)$ nor Deagan (2018, personal communication) found olive jars at La Isabela (established in December 1493) although Deagan $(1987,33)$ reports the recovery of some sherds that have not been published casting doubt on their authenticity. Early-style olive jars were found at La Vega and Puerto Real established in 1503. Both Deagan (personal communication, 2018 ) and Pleguezuelo $(2003,116)$ believe that early-style olive jars are associated with the ascendancy of early transatlantic shipping, which would have post-dated Columbus' first voyage to the Americas.

Although only small amounts were manufactured during the sixteenth century (Deagan 1987, 160), green glass beads (abalorios) are believed to be a secure temporal indicator for the first half of the sixteenth century (Deagan 1987, 169; Smith 1983, 148). Like Spanish olive jars, they were not found at En Bas Saline or La Isabela. The earliest documented evidence for green glass beads (abalorio) is from Nueva Cádiz, Venezuela (Smith and Good 1982), which was established in 1500.

Both the historic and archaeological record suggest that the early-style Spanish olive jar and wire-wound green glass beads were present in the Caribbean in 1500 . This suggests that Spanish goods were incorporated into the Long Bay site at 1500 or afterwards up to the mid-sixteenth century. Of course, all of this would be contradicted if it were found that the European items at the Long Bay site predate 1500 .

The historic record suggests that the Long Bay site already may have been abandoned by the first quarter of the sixteenth century. In 1513 Ponce de León docked on San Salvador for 9-12 days to conduct ship repairs (Kelley 1991; Ober 1908), but found few people on the island. Those he observed hid from the Spanish and there are no accounts of trade and exchange between them and the indigenous inhabitants (Ober 1908, 178). In this scenario, the Lucayans would have acquired the Spanish items found at the Long Bay site sometime between 1500 and 1513 .

As Lightfoot (1995), Torrence and Clarke (2000), and others have argued, prior intercultural interactions and patterns of artifact consumption provide 
precedents for later practices. In other words, early colonial encounters with Europeans and the exchange or acquisition of goods were probably based on existing systems of etiquette, while the consumption, distribution, and circulation of European goods were likely based on functioning economic systems. In the following section, we will examine how trade and exchange of nonlocal materials with foreign peoples (Keegan 1992), the experiences of raiding (Keegan 2015), symbolic associations of non-local items, and the transformation of foreign objects into native categories were integrated into Lucayan life and served as precursors for their assimilation of Spanish items.

\subsection{Trade and Exchange}

The Lucayans participated in long-distance inter-island trade and exchange, as indigenous non-local items are found throughout the whole Lucayan occupational span (Berman 2011; Keegan 1992). Chert artifacts (Berman et al. 1999), non-local pottery, and a variety of artifacts made from igneous and metamorphic materials (e.g., jadeite, diorite, basalt, green schist, quartzite, and quartz crystal) are present at nearly all Lucayan sites (Berman 2011). From Columbus' diary we determine that the Lucayans were knowledgeable of the geography and peoples of neighboring islands including Cuba and Hispaniola (Anderson-Córdova 2017; Berman 2011). Additionally, Columbus observed large canoes holding as many as 40-45 people (Dunn and Kelley 1989, 69), which are believed to have been used for long-distance travel (Keegan 1992). The Lucayans themselves alluded to their trading relationships with people of the Greater Antilles. Columbus noted that the Lucayans told him "there are many and very large ships and many traders" and "great commerce" (Dunn and Kelley 1989, 109, 113). Of course, the reference to the magnitude of the trade may have been an exaggeration on Columbus' part to impress his investors and supporters; nevertheless, the archaeological record attests to the procurement of non-local objects.

The Lucayans also disseminated local and non-local objects among themselves. Only a short time after Columbus left San Salvador, he encountered an individual who was traveling to (Fernandina) Long Island with objects obtained from San Salvador. His canoe held glass beads and two blancas, and items believe to be of local origin: bread, a calabash of water, red powder, and dried leaves (Dunn and Kelley 1989, 85).

The Lucayans were knowledgeable, too, of metals, which circulated throughout the Caribbean prior to the entry of the Spanish (Martinón-Torres et al. 2012; Valcárcel Rojas and Martinón-Torres 2013; Valcárcel Rojas et al. 2010). Two small unworked copper fragments were found at the North Storr's Lake site, a Late Lucayan settlement located on the eastern side of San Salvador (Shaklee 
et al. 2007). Unfortunately, they have not been sourced. Columbus observed gold nose rings, earrings, bracelets, anklets, and chest ornaments on Lucayan men (Dunn and Kelley 1989, 71, 73, 75, 83, 95, 109).

\section{2 $\quad$ Raiding}

Raiding and captive-taking were common practices in small-scale societies (Cameron 2008, 2011; Santos-Granero 2009) and it appears that the Lucayans were subject to regular attacks by people from the northwest, "who came to fight them many times" (Dunn and Kelley 1989, 71) and people from nearby islands who "tried to take them" (Dunn and Kelley 1989, 67). We do not know whether these were other Lucayans or unrelated or distantly related peoples from Florida or the Antilles. While on San Salvador, Columbus and his crew took on board six male captives (Dunn and Kelley 1989, 69). Keegan (2015) notes that the likelihood for hostilities exists in all social interactions and suggests that taking captives was a corollary expression of trade and exchange (see also Cameron 2008; Keeley 1996). The Lucayans, therefore, were no strangers to foreign intrusion and seizure. Due to their familiarity with such behavior, the appropriation of captives may have been viewed as another form of trade (in this sense) with non-local peoples.

\subsection{Symbolic Meanings}

Objects are endowed with meaning according to local cultural logics (Sahlins 1994) and European items possessed physical properties that were metaphorically connected to Lucayan cosmology. As Dietler $(2005,63)$ has noted, "foreign objects must be understood not only for what they represent in the society of origin, but for the culturally specific meaning and perceived utility in the context of consumption." Objects or materials that exhibited shininess, brilliance, or luminescence were (and still are) desired among the native peoples of the Americas (Quilter and Hoopes 2003; Saunders 2003) and the Taíno (Oliver 2000) and Lucayans (Berman 2011), who were closely related to and descended from the Taíno, valued such items. For numerous Amerindians, brightness signified life-giving energies (Saunders 1999, 2003). By virtue of their shininess, translucence, and or light-giving elements, most of the non-local or unusual materials or objects found at Antillean sites exemplify the "aesthetic of brilliance," a concept that epitomizes the "spiritual and creative power of light" (Saunders 2003, 15). The Taíno (Keehnen 2011) and Lucayans (Bate 2011) welcomed shiny items presented to them by the Europeans. Such objects had special resonance for the Lucayans, for like the Taíno (Ostapkowicz 2018), they fit innately into their symbolic calculus.

Olfactory, auditory, and tactile experiences play significant roles in the ways of knowing, living, and meaning-making among non-Western peoples; 
for Amerindians, they constitute what Saunders $(2003,17)$ calls "a holistic phenomenological unity". Copper produces a unique odor, which was regarded to have been highly appealing (Berman 2011; Falchetti 2003; Valcárcel Rojas and Martínon-Torres 2013; Valcárcel Rojas et al. 2010). The analyzed metal objects found at the Long Bay site, as well as the unworked pieces of copper from North Storr's Lake, possessed high percentages of copper that may have emanated such a scent. Certain sounds also held and conveyed cosmologicallylinked symbolic meanings (Hosler 1994), suggesting why the Lucayans and Taíno sought out hawk bells.

Colors, too, served as visual metaphors. The colors of many of the European objects corresponded to hues in the Lucayan spectrum and objects displaying those colors may have been accepted, even sought, on that basis, as has been observed among other Amerindians (Miller and Hamell 1986). Green, red, and yellow Spanish beads, textiles, and metal objects were most likely considered equivalent to guanín (Oliver 200o). They were also the colors of the parrots (considered to be a form of guanin) (Oliver 200o), which the Lucayans presented to the Spanish during their encounter with Columbus (Dunn and Kelley 1989). Ostapkowicz $(2018,166)$ argues that green glass beads, by virtue of their color, size, and physical characteristics held special significance for the Taíno and fit into a prior system of bead manufacture. According to her, the color green was associated with jadeite, which was regarded as possessing exotic status. This can be argued for the Lucayans, too, since jadeite and other greenstones do not occur naturally in the Bahama archipelago. The Lucayans obtained jadeite from distant, non-local sources, accessed only via water transport. Moreover, the size and shape of the beads lie in the range of Lucayan shell beads found throughout the Lucayan sequence (Gnivecki 2006). In sum, the materials, colors, smells, and other properties of indigenous non-local items and the European goods were associated with and served as metaphors for remoteness and distant locales (sensu Helms 1988), which the Spanish and their objects represented. The notion of foreignness was a routinized part of the Lucayan belief system and something that was appreciated, not feared.

\subsection{Artifact Modification}

As we have proposed, the Lucayans classified European objects in the same categories as indigenous non-local items. While most of the objects at the Long Bay site appear to have been unmodified, Brill et al. $(1987,256)$ found that the blanca was scratched and possibly hammered. They suggest that these modifications might represent attempts at perforation, so that the object could have been worn as a bead or pendant. The "D"-ring and belt buckle had the potential to be worn as pendants or other kinds of ornaments, as well. Silliman (2009) 
and others have noted that objects do not have to be transformed physically to become indigenous items.

Through the lens of artifact discard patterns, we see that European objects were treated the same way as indigenous local and non-local objects. At the Long Bay site, the European items were found intermingled with local and non-local (i.e., Antillean) artifacts. As another example, several melado sherds were found on a limestone shelf in close association with a greenstone petaloid axe and a few sherds of Lucayan pottery suggesting that the non-local artifacts, no matter their origin, were regarded in similar ways. Because they were consumed in a like manner, we suggest the items were recontextualized, i.e., transformed into Lucayan objects in use and meaning (sensu Silliman 2009). Samson (2010), Valcárcel Rojas, Samson, and Hoogland (2013, 29) and Hofman et al. (2014) have suggested that the occupants of El Cabo regarded European goods similarly, for they, too, were found interspersed in house sweepings with local items and food waste.

\section{5}

\section{Discussion}

The Lucayans secured European items through a variety of pathways. These, along with indigenous taste (sensu Stahl 2002) and past practice influenced the manner in which the objects were perceived and how they were socialized into local contexts. Some objects may never have entered Lucayan systems, such as those misplaced or discarded by the Spanish. Moreover, they may have become to be regarded suspiciously once the Lucayans recognized Spanish intentions to remove the Lucayans from their homelands. The low volume of recovered objects may be linked to a variety of factors including their rapid insertion into native exchange systems, their assignment to special curated contexts, and to recovery techniques, which, with the exception of the Long Bay site excavations, may not have been sufficiently fine-grained to retain tiny items.

Lucayan consumption of European items was motivated by indigenous economic and political practices driven by symbolic-ideological factors. The archaeological evidence demonstrates that non-local items were a regular feature of Lucayan household and most likely political economies (not examined here), and that acquisition through trade, exchange, and gift-giving with non-local peoples and inter-island down-the-line trade and exchange with indigenous peoples occurred regularly. Interacting with foreigners - even those who took them captives - was commonplace. Accustomed to non-local items and peoples, the Lucayans embraced Spanish goods because they possessed 
characteristics consistent with their cosmovision, making them and regarding them as their own. The remoteness of the sources, either geographical or metaphorical, rendered the objects similar to others with which they were familiar. Some of the items' sensory properties such as iridescence, color, smell, texture, and sound fit into the Lucayan symbolic reservoir.

Thomas (1991) has noted that in spite of the distinctiveness and newness of European objects in the eyes of indigenous peoples, such objects often preserve a "prior order" and are modified to resemble preexisting objects. The attempted perforation of the blanca is just such an example of altering a foreign object to fit a preexisting template (should it, in fact have been performed by a Lucayan). The Lucayans do not appear to have modified the other European objects found at the Long Bay site, however. Similarly, we have no evidence that European goods were embedded into the fabric of Lucayan objects, but, due to the perishable nature of much of material Lucayan culture, these may have not survived the archaeological record or may have been curated in inaccessible locations.

\section{$6 \quad$ Conclusions}

The Lucayans interacted with European items in an indigenous colonial space that differed geographically and politically from the Greater Antilles. The absence of close or sustained interaction between the Europeans and the Lucayans due to the geographical distance of the Bahama islands from the colonial heartland, the lack of direct colonial control, the varied, brief, intermittent nature of Lucayan-Spanish contact, and ultimately the violent conditions under which they interacted did not encourage the creation of a large body of reworked, repurposed, or hybridized items. While the European objects presented novel shapes, colors, forms, and materials, the Lucayans found the items to be analogous to materials they knew and understood symbolically and thus there may have been less desire to physically modify them. This is not to deny Lucayan agency, but is suggested as a means to explore why little to no modification is observed on the European articles found at the Long Bay site. While the biographies of European objects found in Lucayan contexts share some similarities with those from other early colonial contexts, there are differences between them. These can be attributed to historical factors. And, while it was objects that first facilitated Spanish-indigenous relations, in the end, it was the indigenous peoples, not exclusively the objects that were recontextualized, redefined, and physically reworked as commodities. 


\section{Acknowledgments}

This article could not have been achieved without the support of numerous people. In particular, the authors thank Mrs. Kathy Doan Gerace and the late Dr. Donald T. Gerace for their interest in and encouragement of our research, which has allowed us a panoramic grasp of the Lucayans from their earliest peopling of the Bahama archipelago to their final days on the islands. We want to especially thank Kathy for providing the photograph of the glass beads and for helping to locate more of Charles Hoffman's field records. They revealed much more about the Long Bay site than what has appeared in publications and these findings have done much to enhance this article. We recognize and thank, too, the support provided by the staff of the Gerace Research Centre, University of the Bahamas, who have always welcomed us to San Salvador Island and gone out of their way to provide a comfortable working context. Dr. Michael Pateman, Director of the Turks \& Caicos National Museum Foundation, Grand Turk, Turks \& Caicos Islands has championed our research and analyses. For this, we are profoundly appreciative. We would be remiss if we did not honor the late Dr. Charles Hoffman who excavated the Long Bay site. Without his work and that of his legions of students and volunteers, the Spanish presence in the Bahamas would have continued to remain buried as a footnote in history books. Berman would like to thank Miami University's College of Arts and Science, which granted her a spring 2017 assigned research leave; this gave her the time and space to read and think through the many issues reflected in this work. Additionally, we are grateful to Eric Johnson, Miami University Numeric and Spatial Data Services Librarian, who transformed 35 year old slides into the digital images presented here. And, finally, we thank the citizens of the Commonwealth of the Bahamas, who have welcomed us for three decades. We hope that they will find our discoveries and interpretations meaningful and worthy of their generous hospitality.

\section{References}

Anderson-Córdova, Karen F. 2017. Surviving Spanish Conquest. Indian Fight, Flight, and Cultural Transformation in Hispaniola and Puerto Rico. Tuscaloosa: University of Alabama Press.

Bate, Emma. 2011. "Technology and Spanish Contact: Analysis of Artifacts from the Long Bay Site, San Salvador, Bahamas." PhD diss., Indiana University.

Benjamin, Thomas. 2009. The Atlantic World. Europeans, Africans, and Their Shared History, 1400-1900. Cambridge: Cambridge University Press. 
Berman, Mary Jane. 2011. "Good as Gold: The Aesthetic Brilliance of the Lucayans." In Islands in the Stream: Migration, Seafaring, and Interaction in the Caribbea, edited by L. Antonio Curet and Mark W. Hauser, 104-134. Tuscaloosa: University of Alabama Press.

Berman, Mary Jane, and Perry L. Gnivecki. 1995. "The Colonization of the Bahama Archipelago: A Reappraisal." World Archaeology 26 (3): 421-441.

Berman, Mary Jane, and Perry L. Gnivecki. 2000. "Long Bay Site (SS9) Field Notes." Unpublished notes in possession of authors.

Berman, Mary Jane, and Deborah M. Pearsall. 2008. "At the Crossroads: Starch Grain and Phytolith Analyses in Lucayan Prehistory." Latin American Antiquity 19 (2): 181-203.

Berman Mary, Jane, and Deborah M. Pearsall. 2018. "Crop Dispersal and Lucayan Tool Use: Creating the Transported Landscape in the Central Bahamas. Evidence from Starch Grain, Phytolith, Macrobotanical, and Artifact Studies." Ms. On file with Mary Jane Berman.

Berman, Mary Jane, April K. Sievert, and Thomas R. Whyte. 1999. "Form and Function of Bipolar Lithic Artifacts from the Three Dog Site, San Salvador, Bahamas." Latin American Antiquity 10 (4): 415-432.

Berman, Mary Jane, Perry L. Gnivecki, and Michael P. Pateman. 2013. "The Bahama Archipelago." In The Oxford Handbook of Caribbean Archaeology, edited by William F. Keegan, Corinne L. Hofman, and Reniel Rodríguez Ramos, 264-28o. New York: Oxford University Press.

Brain, Jeffrey. 1975. "Artifacts of the Adelantado." In Conference on Historic Sites Archaeology Papers Volume 8, edited by Stanley South, 129-134. Columbia: The South Carolina Institute of Archaeology and Anthropology, University of South Carolina.

Brill, Robert, I. Lynus Barnes, Stephen S. Tong, Emile C. Joel, and Martin J. Murtagh. 1987. "Laboratory Studies of Some European Artifacts Excavated on San Salvador, Bahamas." In Proceedings of the ist San Salvador Conference: Columbus and His World, compiled by Donald T. Gerace, 247-292. Fort Lauderdale: College Center of the Finger Lakes and San Salvador: Bahamian Field Station.

Burns, Sir Alan. 1965. History of the British West Indies, Revised and Edition. London: George Allen and Unwin.

Cameron, Catherine M. 2008. "Captives in Prehistory: Agents of Social Change." In Invisible Citizens: Captives and Their Consequences, edited by Catherine M. Cameron, 1-24. Salt Lake City: University of Utah Press.

Cameron, Catherine M. 2011. "Captives and Culture Change: Implications for Archaeology." Current Anthropology $5^{2}$ (2): 169-209.

Charlton, Thomas. 1968. "Post-Conquest Aztec Commerce: Implications for Archaeological Interpretations." Florida Anthropologist 21 (4): 96-101. 
Cipolla, Craig N. 2013. Becoming Brothertown: Native American Ethnogenesis and Endurance in the Modern World. Tucson: The University of Arizona Press.

Cipolla, Craig N., ed. 2017. Foreign Objects. Rethinking Indigenous Consumption in American Archaeology. Tucson: The University of Arizona Press.

Cobb, Charles R., ed. 2003. Stone Tool Traditions in the Contact Era. Tuscaloosa: University of Alabama Press.

Cusick, James G. 1991. "Culture Change and Pottery Change in a Taino Village." In Proceedings of the 13th Congress of the International Association for Caribbean Archaeology, Part I, edited by E.N. Ayubi and J.B. Haviser, 446-461. Aruba: Reports of the Archaeological-Anthropological Institute of the Netherlands Antilles, No. 9.

Deagan, Kathleen A. 1987. Artifacts of the Spanish colonies of Florida and the Caribbean, 1500-180o. Vol 1: Ceramics, Glassware and Beads. Washington D.C.: Smithsonian Institution Press.

Deagan, Kathleen A. 1988. "The Archaeology of the Spanish Contact Period in the Caribbean." Journal of World Prehistory 2 (2): 187-225.

Deagan, Kathleen A., ed. 1995. Puerto Real: the Archaeology of a Sixteenth Century Spanish Town in Hispaniola. Gainesville: University Press of Florida.

Deagan, Kathleen A. 2002. Artifacts of the Spanish Colonies of Florida and the Caribbean 1500-180o. Volume 2: Portable Personal Possessions. Washington D.C.: Smithsonian Institution Press.

Deagan, Kathleen A. 2004. "Reconsidering Taíno Social Dynamics After Spanish Conquest: Gender and Class in Culture Contact Studies." American Antiquity 69 (4): 597-626.

Deagan, Kathleen A. and José M. Cruxent. 2002a. Columbus's Outpost Among the Taínos: Spain and America at La Isabela, 1493-1498. Haven: Yale University Press.

Deagan, Kathleen A. and José M. Cruxent. 2002b. Archaeology at La Isabela, America's First European Town. New Haven: Yale University Press.

Dietler, Michael. 1998. "Consumption, Agency, and Cultural Entanglement: Theoretical Implications of a Mediterranean Colonial Encounter." In Studies in Culture Contact: Interaction, Culture Change, and Archaeology, edited by James G. Cusick, 288-315. Carbondale: Southern Illinois University Press.

Dietler, Michael. 2005. "The Archaeology of Colonization and the Colonization of Archaeology: Theoretical Challenges from an Ancient Mediterranean Colonial Encounter." In The Archaeology of Colonial Encounters, edited by Gil J. Stein, 33-68. Santa Fe: School of American Research Advanced Seminar Series.

Dunn, Oliver, and James E Kelley. 1989. The Diario of Christopher Columbus's First Voyage to America 1492-1493. Norman: University of Oklahoma Press.

Falchetti, Ana M. 2003. "The Seed of Life:The Symbolic Power of Gold-Copper Alloys and Metallurgical Transformations." In Gold and Power in Ancient Costa Rica, Panama, 
and Columbia, edited by Jeffrey Quilter and John W. Hoopes, 145-381. Washington DC: Dumbarton Oaks Research Library and Collection.

Gnivecki, Perry L. 1995. "Rethinking "First" Contact." In Proceedings of the 15th Congress of the International Association for Caribbean Archaeology, edited by Ricardo E. Alegría and Miguel Rodríguez, 209-217. San Juan: Centro de Estudios Avanzados de Puerto Rico y el Caribe.

Gnivecki, Perry L. 2006. "What Shell Beads from the Three Dog Site, San Salvador Island, Bahamas, Can Tell Us." Paper presented at the 7 st Annual Meeting of the Society for American Archaeology "Current Research Bahamian Prehistory and Historical Archaeology: Papers in Memory of Charles A. Hoffman," San Juan, Puerto Rico, 26-3o April.

Gnivecki, Perry L. 2011. "Text and Context: The Spanish Contact Period in the Bahama Archipelago." In Proceedings of the 14th Symposium on the Natural History of the Bahamas, edited by Craig Tepper and Ronald Shaklee, 197-211. San Salvador: Gerace Research Centre.

Goggin, John. 1960. The Spanish Olive Jar: An Introductory Study. Yale University Publications in Anthropology, No. 62. New Haven: Yale University Press.

Granberry, Julian. 1979. "Spanish Slave Trade in the Bahamas, 1509-1530: An Aspect of the Caribbean Pearl Industry." Journal of the Bahamas Historical Society 1: 14-15.

Granberry, Julian. 1980. "Spanish Slave Trade in the Bahamas, 1509-1530: An Aspect of the Caribbean Pearl Industry (Continued)." Journal of the Bahamas Historical Society 2: $15^{-17}$.

Granberry, Julian. 1981. "Spanish Slave Trade in the Bahamas, 1509-1530: An Aspect of the Caribbean Pearl Industry (Last Part)." Journal of the Bahamas Historical Society 3: 17-19.

Harisse, Henry. 1961. The Discovery of North America (1892). Amsterdam: N. Israel.

Helms, Mary W. 1988. Ulysses' Sail: An Ethnographic Odyssey of Power, Knowledge, and Geographical Distance. Princeton: Princeton University Press.

Hofman, Corinne L., Angus A.A. Mol, Menno L.P. Hoogland, and Roberto Valcárcel Rojas. 2014. "Stage of Encounters: Migration, Mobility, and Interaction in the Precolonial and Early Colonial Caribbean." World Archaeology 46 (4): 590-6o9.

Hoffman, Charles A. 1987a. "Archaeological Investigations at the Long Bay Site, San Salvador, Bahamas." American Archaeology 6: 97-102.

Hoffman, Charles A. 1987b. "Archaeological Investigations at the Long Bay Site, San Salvador, Bahamas." In Proceedings of the ist San Salvador Conference: Columbus and His World, compiled by Donald T. Gerace, 237-245. Fort Lauderdale: College Center of the Finger Lakes and San Salvador: Bahamian Field Station.

Hoffman, Paul E. 1990. A New Andalusia and A Way to the Orient: A History of the American Southeast During the 16th Century. Baton Rouge: Louisiana State University Press. 
Hosler, Dorothy. 1994. The Sounds and Colors of Power: The Sacred Metallurgical Technology of Ancient West Mexico. Cambridge: The MIT Press.

Keegan, William F. 1992. The People Who Discovered Columbus: The Prehistory of the Bahamas. Gainesville: University Press of Florida.

Keegan, William F. 2015. "Mobility and Disdain: Columbus and Cannibals in the Land of Cotton." Ethnohistory 62 (1):1-15.

Keehnen, Floris W.M. 2011. "Conflicting Cosmologies. The Exchange of Brilliant Objects Between the Taíno of Hispaniola and the Spanish." In Communities in Contact: Essays in Archaeology, Ethnohistory and Ethnography of the Amerindian CircumCaribbean, edited by Corinne L. Hofman and Anne van Duijvenbode, 253-268. Leiden: Sidestone Press.

Keeley, Lawrence H. 1996. War Before Civilization. New York: Oxford University Press.

Keith, Donald H., Jim A. Duff, Steve R. James, Thomas J. Oertling, and Joe J. Simmons. 1984. "The Molasses Reef Wreck, Turks and Caicos, BWI: A Preliminary Report." The International Journal of Nautical Archaeology and Underwater Exploration 13 (1): $45^{-63 .}$

Kelley, James E. Jr. 1991. “Juan Ponce de Leon's Discovery of Florida: Herrera's Narrative Revisted." Revista de Historia de América 111: 31-65.

Kopytoff, Igor. 1986. "The Cultural Biography of Things: Commoditization as Process." In The Social Life of Things. Commodities in Cultural Perspective, edited by Arjun Appadurai, 64-91. Cambridge: Cambridge University Press.

Kulstad-González, Pauline M. 2015. "Striking it Rich in Americas' First Boom Town: Economic Activity at Concepción de la Vega." In Archaeology of Culture Contact and Colonialism in Spanish and Portuguese America, edited by Pedro Paulo A. Funari and María Ximena Senatore, 313-337. New York: Springer.

Lightfoot, Kent G. 1995. "Culture Contact Studies: Redefining the Relationship Between Prehistoric and Historical Archaeology." American Antiquity 6o (2): 199-217.

Lightfoot, Kent G., and Antoinette Martinez. 1995. "Frontiers and Boundaries in Archaeological Perspective." Annual Review of Anthropology 24: 471-492.

Lightfoot, Kent G., and William Simmons. 1998. "Culture Contact in Protohistoric California: Social Contexts of Native and European Encounters." Journal of California and Great Basin Anthropology 20 (2): 138-170.

Martinón-Torres, Marcos, Roberto Valcárcel Rojas, Juanita Sáenz Samper, María Filomena Guerra. 2012. "Metallic Encounters in Cuba: The Technology, Exchange and Meaning of Metals." Journal of Anthropological Archaeology 31 (4): 439-454.

Miller, Christopher F., and George F. Hamell 1986. "A New Perspective on Indian-White Contact: Cultural Symbols and Colonial Trade." Journal of American History 73: 311-328.

Morison, Samuel Eliot. 1942. Admiral of the Ocean Sea: A Life of Christopher Columbus, Volume 1. Boston: Little, Brown, and Company. 
Newsom, Lee A., and Elizabeth S. Wing. 2004. On Land and Sea: Native American Uses of Biological Resources in the West Indies. Tuscaloosa: University of Alabama Press.

Ober, Frederick A. 1908. Juan Ponce de Leon. New York: Harper and Brothers Publishers. Oland, Maxine. 2014. "With the Gifts and Good Treatment That He Gave them': Elite Maya Adoption of Spanish Material Culture at Progresso Lagoon, Belize." International Journal of Historical Archaeology 18 (4): 643-667.

Oliver, José. 200o. "Gold Symbolism Among Caribbean Chiefdoms: of Feathers, Ceibas, and Guanín Power Among Taíno Elites.” In Precolumbian Gold Technology, Style, and Iconography, edited by Colin McEwan, 196-219. London: British Museum Press.

Ortega, Elpidio J., and Carmen Fondeur. 1978. Estudio d la Cerámica del Periodo Indohispano de la Antigua Concepciòn de la Vega. Santo Domingo: Funcaciòn Ortega Alvárez.

Ostapkowicz, Joanna. 2018. "New Wealth from the Old World: Glass, Jet and Mirrors in the Late $15^{\text {th }}$ to Early 16 th Century Indigenous Caribbean." In Gifts, Goods, and Money. Comparing Currency and Circulation Systems in Past Societies, edited by Dirk Brandherm, Elon Heymans and Daniela Hofmann, 153-193. Oxford: Archaeopress.

Parry, John H., and Robert G. Keith, eds. 1984. New Iberian World: A Documentary History of the Discovery and Settlement of Latin America to the Early 17th Century, Volumes I-II. New York: Times Books and Hector and Rose.

Peterson, Mendel. 1974. "Exploration of a 16th-Century Bahaman Shipwreck." National Geographic Society Research Reports, 1967, Projects 231-242. Washington, DC.

Pleguezuelo, Alfonso. 2003. "Ceramics, Business, and Economy." In Cerámica Y Cultura: The Story of Spanish and Mexican Mayólica, edited by Robin Farwell Gavin, Donna Pierce, and Alfonso Pleguezuelo, 102-121. Albuquerque: University of New Mexico Press.

Pohl, Frederick J. 1966. Amerigo Vespucci, Pilot Major. New York: Octogon Books.

Quilter, Jeffrey, and John W. Hoopes, eds. 2003. Gold and Power in Ancient Costa Rica, Panama, and Colombia. Washington D.C.: Dumbarton Oaks, Trustees for Harvard University.

Quinn, David B. 1979. New American World: A Documentary History of North America to 1612, Volume I. New York: Arno Press and Hector Bye.

Rodríguez-Alegría, Enrique. 2008. "Narratives of Conquest, Colonialism, and Cutting Edge Technology." American Anthropologist 110 (1): 33-43.

Rodríguez-Alegría, Enrique, Franz Scaramelli and Ana María Navas. 2015. “Technological Transformations: Adaptationist, Relativist, and Economic Models in Mexico and Venezuela." In Archaeology of Culture Contact and Colonialism in Spanish and Portuguese America, edited by Pedro Paulo A. Funari and María Ximena Senatore, 53-77. New York: Springer. 
Rouse, Irving B. 1942. Archaeology of the Maniabón Hills, Cuba. Yale University Publications in Anthropology, Number 26. New Haven: Yale University Press.

Sahlins, Marshall D. 1994. "Cosmologies of Capitalism: The Trans-Pacific Sector of "The World System'." In Culture/Power/History. A Reader in Contemporary Social Theory, edited by Nicholas B. Dirks, Geoff Eley, and Sherry B. Ortner, 412-455. Princeton: Princeton University Press.

Samson, Alice V.M. 2010. Renewing the House: Trajectories of Social Life in the Yucayeque (Community) of El Cabo, Higüey, Dominican Republic, AD 800 to 1504. Leiden: Sidestone Press.

Santos-Granero, Fernando. 2009. Slavery, Predation, and the Amerindian Political Economy of Life. Austin: University of Texas Press.

Sauer, Carl O. 1966. The Early Spanish Main. Berkeley: University of California Press.

Saunders, Nicholas J. 1999. "Biographies of Brilliance: Pearls, Transformation, and Being, c. A.D. 1492." World Archaeology 31 (2): 243-257.

Saunders, Nicholas J. 2003. "Catching the Light': Technologies of Power and Enchantment in Pre-Columbian Goldworking." In Gold and Power in Ancient Costa Rica, Panama, and Colombia, edited by Jeffrey Quilter and John W. Hoopes, 15-49. Washington, DC: Dumbarton Oaks, Trustees for Harvard University.

Shaklee, Ronald, Gary Fry, and Thomas Delvaux. 2007. "An Archaeological Report on the Storr's Lake Site, San Salvador: 1995-2005." Bahamas Naturalist and Journal of Science 1: 31-39.

Silliman, Stephen W. 2005. "Culture, Contact or Colonialism? Challenges in the Archaeology of Native North America." American Antiquity 70 (1): 55-74.

Silliman, Stephen W. 2009. "Change and Continuity, Practice and Memory: Native American Persistence in Colonial New England." American Antiquity 74 (2): 211-230.

Sinelli, Peter T. 2010. "All Islands Great and Small: The Role of Small Cay Environments in Indigenous Settlement Strategies in the Turks and Caicos Islands." PhD diss., University of Florida.

Smith, Marvin. 1983. "Chronology from Glass Beads: The Spanish Period in the Southeast, c. A.D. 1513-1670." In Proceedings of the 1982 Glass Trade Bead Conference, edited by C. Hayes, 147-158. Rochester: Rochester Museum and Science Center Research Records, No. 16.

Smith, Marvin, and Elizabeth F. Good. 1982. Early Sixteenth Century Glass Beads in the Spanish Colonial Trade. Greenwood: Cottonlandia Museum Publications.

Smith, Roger C., Donald H. Keith, and Denise Lakey. 1985. "The Highbourne Cay Wreck: Further Exploration of a 16th Century Bahaman Shipwreck." Journal of Nautical Archaeology and Underwater Exploration 14: 63-72.

Stahl, Alan. 1992. "The Coinage of La Isabela, 1493-1498." Numismatist 105 (10): 1399-1402. 
Stahl, Ann B. 2002. "Colonial Entanglements and the Processes of Taste: An Alternative to Logocentric Approaches." American Anthropologist 104 (3): 827-845.

Sullivan, Shaun D. 1981. "Prehistoric Patterns of Exploitation and Colonization in the Turks and Caicos Islands." PhD diss., University of Illinois.

Thomas, Nicholas. 1991. Entangled Objects: Exchange, Material Culture, and Colonialism in the Pacific. Cambridge: Harvard University Press.

Torrence, Robin, and Anne Clarke. 200o. "Negotiating Difference: Practice Makes Theory for Contemporary Archaeology in Oceania." In The Archaeology of Difference, Negotiating Cross-Cultural Engagements in Oceania, edited by Robin Torrence and Anne Clarke, 1-31. London: Routledge.

Turnbaugh, William A. 1993. "Assessing the Significance of European Goods in Seventeenth-Century Narragansett Society." In Ethnohistory and Archaeology: Approaches to Postcontact Change in the Americas, edited by J. Daniel Rogers and Samuel M. Wilson, 133-16o. New York: Plenum Press.

Valcárcel Rojas, Roberto. 2016. Archaeology of Early Colonial Interaction at Chorro de Maíta, Cuba. Gainesville: University Press of Florida.

Valcárcel Rojas, Roberto, and Marcos Martínon-Torres. 2013. "Metals in the Indigenous Societies of the Insular Caribbean." In The Oxford Handbook of Caribbean Archaeology, edited by William F. Keegan, Corinne L. Hofman, and Reniel Rodríguez Ramos, 504-522. New York: Oxford University Press.

Valcárcel Rojas, Roberto, Alice V.M. Samson and Menno L.P. Hoogland. 2013. "IndoHispanic Dynamics: From Contact to Colonial Interaction in the Greater Antilles." International Journal of Historical Archaeology 17 (1): 18-39.

Valcárcel Rojas, Roberto, Marcos Martínon-Torres, Jago Cooper, and T. Rehren. 2010. "Turey Treasure in the Caribbean: Brass and Indo-Hispanic Contact at Chorro de Maíta, Cuba." In Beyond the Blockade, New Currents in Cuban Archaeology, edited by Susan Kepec, L. Antonio Curet, and Gabino La Rosa Corzo, 106-125. Tuscaloosa: University of Alabama Press.

Weddle, Robert S. 1985. Spanish Sea: The Gulf of Mexico in North American Discovery 1500-1685. College Station: Texas A\&M University Press.

Winter, John, and Mark Gilstrap. 1991. "Preliminary Results of Ceramic Analysis and the Movements of Populations into the Bahamas." In Proceedings of the 12th Congress of the International Association for Caribbean Archaeology, edited by L.S. Robinson, 371-386. Martinique: International Association for Caribbean Archaeology. 